Research Article

\title{
Biochemical comparison of two Hypostomus populations (Siluriformes, Loricariidae) from the Atlântico Stream of the upper Paraná River basin, Brazil
}

\author{
Kennya F. Ito ${ }^{1}$, Erasmo Renesto ${ }^{1}$ and Cláudio H. Zawadzki ${ }^{2}$ \\ ${ }^{1}$ Universidade Estadual de Maringá, Departamento de Biologia Celular e Genética, Maringá, PR, Brazil. \\ ${ }^{2}$ Universidade Estadual de Maringá, Departamento de Biologia/Nupelia, Maringá, PR, Brazil.
}

\begin{abstract}
Two syntopic morphotypes of the genus Hypostomus - $H$. nigromaculatus and $H$. cf. nigromaculatus (Atlântico Stream, Paraná State) - were compared through the allozyme electrophoresis technique. Twelve enzymatic systems (AAT, ADH, EST, GCDH, G3PDH, GPI, IDH, LDH, MDH, ME, PGM and SOD) were analyzed, attributing the score of 20 loci, with a total of 30 alleles. Six loci were diagnostic (Aat-2, Gcdh-1, Gpi-A, Idh-1, Ldh-A and Mdh-A), indicating the presence of interjacent reproductive isolation. The occurrence of few polymorphic loci acknowledge two morphotypes, with heterozygosity values $\mathrm{He}=0.0291$ for $H$. nigromaculatus and $\mathrm{He}=0.0346$ for $H$. cf. nigromaculatus. $F_{\text {IS }}$ statistics demonstrated fixation of the alleles in the two morphotypes. Genetic identity (I) and distance $(D)$ of Nei (1978) values were I $=0.6515$ and $D=0.4285$. The data indicate that these two morphotypes from the Atlântico Stream belong to different species.
\end{abstract}

Key words: allozymes, Hypostomus nigromaculatus, fish genetics, genetic distance and polymorphism.

Received: March 18, 2008; Accepted: September 5, 2008.

\section{Introduction}

The Neotropical region, encompassing southern Mexico and Central and South America, possesses the richest ichthyofauna in the world, with about 8,000 freshwater species (Schaefer, 1998). The order Siluriformes includes 34 families, 412 genera and more than 2,405 species (Nelson, 1994). Among the families belonging to this order, Loricariidae possesses more than 600 described species (Reis et al., 2003), representing one of the largest families worldwide. This wide diversity has resulted in species identification problems, with many new species constantly being described (Pereira and Oyakawa, 2003; Cardoso and Silva, 2004). The family Loricariidae has been habitually divided into six subfamilies (Reis et al., 2006). In the subfamily Hypostominae there are still many species that are not well defined, mainly due to wide intraspecific variation in morphology and color pattern. This happens mainly in the genus Hypostomus (Weber, 2003; Birindelli et al., 2007; Jerep et al., 2007). Biochemical markers are products of gene expression (proteins or secondary compounds) (e.g. isozymes). These are different molecular forms of an enzyme catalyzing the same reaction in the cell (Alfenas, 2006). Isozyme electrophoresis has been used with success

Send corresponce to Erasmo Renesto. Departamento de Biologia/Nupelia, Universidade Estadual de Maringá, Av. Colombo 579, 87020-900 Maringá, PR, Brazil. E-mail: erenesto@ hotmail.com. to settle doubts regarding the taxonomic status of undescribed species of the Brazilian ichthyofauna (Renesto et al., 2000, 2001, 2007; Zawadzki et al., 2000, 2004).

Some specimens of Hypostomus nigromaculatus (Schubart, 1964) and a similar morphotype, called in this work Hypostomus cf. nigromaculatus, were collected in the Atlântico Stream, near Mandaguaçu, Paraná State, in the south of Brazil. Hypostomus nigromaculatus always presents distinct black spots on the body and fins, while $H$. cf. nigromaculatus usually presents clear gray spots, but possibly some dark spots, which made correct separation of the two morphotypes difficult, mainly in juveniles.

The main objective of the present work was to compare the electrophoretic patterns of syntopic samples of Hypostomus nigromaculatus and Hypostomus cf. nigromaculatus, in order to discover whether they belong to the same species, as well as to estimate the degree of genetic differentiation between them.

\section{Material and Methods}

Specimens of Hypostomus were collected in the Atlântico Stream (Figure 1) $\left(23^{\circ} 18^{\prime} 55^{\prime \prime} \mathrm{S} ; 5^{\circ} 00^{\prime} 55^{\prime \prime} \mathrm{W}\right)$. The Atlântico Stream is a small stream branching from the Pirapó River, a tributary of the Paranapanema River (Mandaguaçu, northwestern Paraná State, southern Brazil). Thirty fish were collected, 15 of which were identified as Hypostomus nigromaculatus and 15 as Hypostomus cf. 


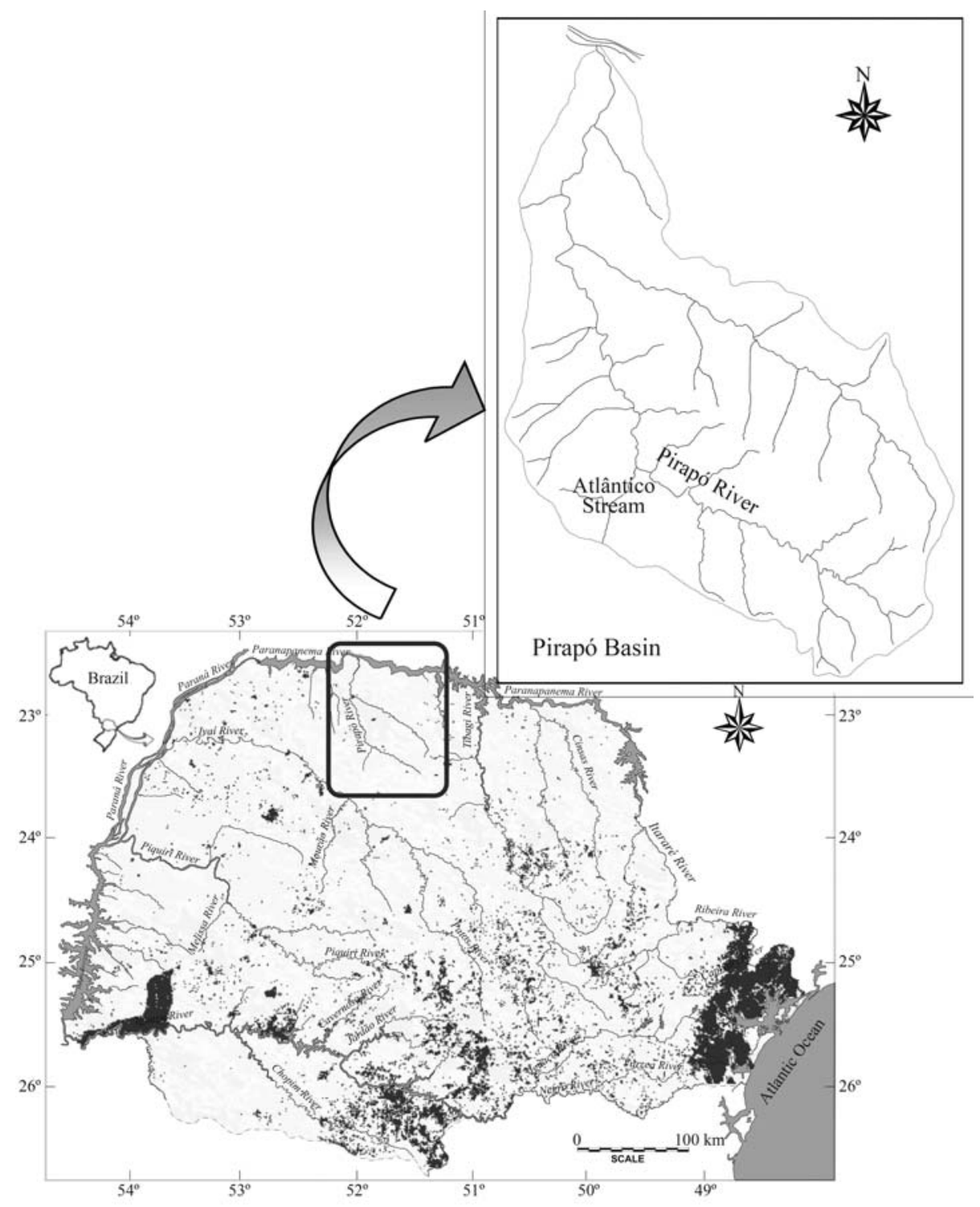

Figure 1 - Paraná State hydrographic map. The small rectangle shows the location of the Pirapó River basin. The rectangle above shows the location of the Atlântico Stream in this basin.

nigromaculatus, identification being based on morphological characters (Figure 2). All the specimens were collected on the same day and in the same place, by using a nylon thread cast net and conserved whole in liquid nitrogen. Samples of tissue from the muscles, liver, eyes, stomach, heart, kidneys and gills were homogenized with a plastic stick in propylene tubes $(1.5 \mathrm{~mL})$ with $100 \mu \mathrm{L}$ of Tris- $\mathrm{HCl}$ $0.02 \mathrm{M}, \mathrm{pH} 7.5$ buffer. Due to the presence of a great amount of fat in the liver, $100 \mu \mathrm{L}$ of carbon tetrachloride $\left(\mathrm{CCl}_{4}\right)$ was added to the tube (Pasteur et al., 1988).

The enzyme extract was applied to the gel using Whatman $3 \mathrm{MM}{ }^{\circledR}$ paper wicks (4 $\mathrm{mm}$ x $8 \mathrm{~mm}$ ) soaked with the samples, which were then submitted to continuous horizontal electrophoresis, under cooling. The gels were prepared with $15 \mathrm{~g} \%$ of corn starch (Val et al., 1981). Three buffer solutions were used: Tris $0.135 \mathrm{M} / \mathrm{Citric}$ acid
$0.043 \mathrm{M} \mathrm{pH} 7.0$ (TC), Tris $0.18 \mathrm{M} /$ Boric acid 0.1/EDTA $0.004 \mathrm{M} \mathrm{pH} 8.6$ (TBE) and Tris $0.1 \mathrm{M} /$ Maleic acid $0.1 \mathrm{M} /$ EDTA $0.01 \mathrm{M} \mathrm{pH} 7.4$ (TEM). A voltage gradient of $60 \mathrm{~V}$ (measured in the extremities of the gel) was applied for $16 \mathrm{~h}$. After electrophoresis, the gel was horizontally sliced length-wise into two slabs, which were incubated with specific staining solutions according to Murphy et al., (1996).

Genetic variability was estimated by using Nei (1978) (He and Ho) average heterozygosity. The homogeneity of allele frequencies between populations was verified through a contingency chi-squared test. Unbiased genetic identity (I) and genetic distance (D) were also calculated according to Nei (1978). All of the estimates were calculated using POP GENE 1.31 software (Yeh and Boyle, 1997). 

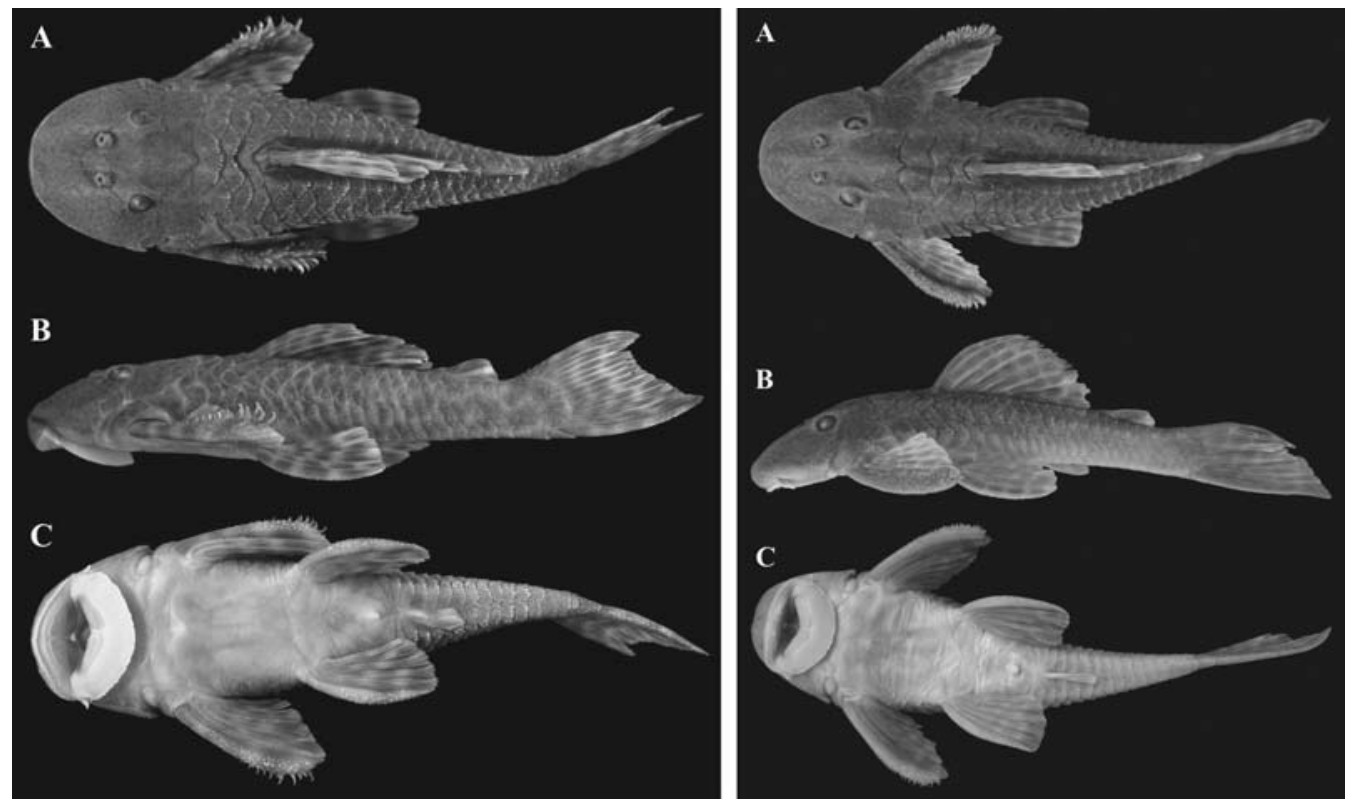

Figure 2 - Hypostomus nigromaculatus (left, standard length $=75 \mathrm{~mm}$ ) and Hypostomus $\mathrm{cf}$. nigromaculatus (right, standard length $=101.3 \mathrm{~mm}$ ). A. Dorsal view. B. Lateral view. C. Ventral view.

\section{Results}

Tissues of Hypostomus nigromaculatus and Hypostomus cf. nigromaculatus were analyzed by corn starch gel electrophoresis using 12 enzymatic systems (Table 1). Twenty loci were detected (Table 2), presenting a total of 30 alleles. Figure 3 displays the electrophoretic pattern of each enzyme revealed for the two analyzed Hypostomus morphotypes. Six loci (Aat-2, Gcdh-1, Gpi-A, Idh-1, $L d h-A$ and $M d h-A$ ) were diagnostic, i.e. they possess different alleles with $100 \%$ frequency in each morphotype.

The electrophoretic patterns of the 12 enzymatic systems were similar to those found by Zawadzki et al. (2001) for three species of Hypostomus from the Iguaçu River, except for esterase (EST), which had not been analyzed by these authors. The occurrence of few polymorphic loci was verified for both morphotypes: Gpi-A and Gpi-B for $H$. nigromaculatus, and $L d h-B$ and $G p i-B$ for $H$. cf. nigromaculatus.

Low polymorphism can also be verified by the effective number of alleles (Ae). As regards H. nigromaculatus, $G p i-A(\mathrm{Ae}=1.49)$ and $G p i-B(\mathrm{Ae}=1.30)$ were polymorphic, with an average of $1.04 \pm 0.12$ alleles per locus. As to $H$. cf. nigromaculatus, two loci were polymorphic, Gpi-B $(\mathrm{Ae}=1.38)$ and $L d h-B(\mathrm{Ae}=1.64)$, with an average of $1.05 \pm 0.16$ alleles per locus.

We did not detect deviations from Hardy-Weinberg equilibrium at the polymorphic loci of $H$. nigromaculatus $(\mathrm{p}>0.05)$.

The occurrence of few polymorphic loci was verified for the two morphotypes. Mean values of expected and observed heterozygosity for all the loci of $H$. cf. nigromaculatus were $\mathrm{He}=0.0346 \pm 0.1082$ and
Table 1 - Enzyme, Enzyme Commission number (EC n.), tissue, buffer and quaternary structure (QE) of enzymes analyzed in Hypostomus, Hypostomus nigromaculatus and Hypostomus cf. nigromaculatus from the Atlântico Stream (Paraná State, Brazil) by the corn-starch gel electrophoresis technique.

\begin{tabular}{|c|c|c|c|c|}
\hline Enzymes & E C n. & Tissue & Buffer & QE \\
\hline $\begin{array}{l}\text { Alcohol } \\
\text { dehydrogenase(ADH) }\end{array}$ & 1.1.1.1 & $\mathrm{G} / \mathrm{L}$ & TBE/TEM & $\mathrm{D}$ \\
\hline $\begin{array}{l}\text { Aspartate } \\
\text { aminotransferase (AAT) }\end{array}$ & 2.6.1.1 & $\mathrm{L}$ & TEM & $\mathrm{D}$ \\
\hline Esterase (EST) & 3.1.1.1 & $\mathrm{G} / \mathrm{L}$ & TBE/TEM & Mo \\
\hline $\begin{array}{l}\text { Glucose dehydrogenase } \\
\text { (GCDH) }\end{array}$ & 1.1.1.118 & $\mathrm{L}$ & TEM & $\mathrm{D}$ \\
\hline $\begin{array}{l}\text { Glucose-6-phosphate } \\
\text { isomerase (GPI) }\end{array}$ & 5.3 .1 .9 & $\mathrm{G} / \mathrm{L} / \mathrm{M}$ & $\mathrm{TC}$ & $\mathrm{D}$ \\
\hline $\begin{array}{l}\text { Glycerol-3-phosphate } \\
\text { dehydrogenase }\left(\mathrm{G}_{3} \mathrm{PDH}\right)\end{array}$ & 1.1.1.8 & M & $\mathrm{TC}$ & $\mathrm{D}$ \\
\hline $\begin{array}{l}\text { Isocitrate dehydrogenase } \\
\text {-NADP+ (IDHP) EC } \\
1.1 .1 .42\end{array}$ & 1.1 .1 .42 & $\mathrm{G} / \mathrm{L} / \mathrm{M}$ & TC/TEM & $\mathrm{D}$ \\
\hline $\begin{array}{l}\text { L-Lactate dehydrogenase } \\
\text { (LDH) }\end{array}$ & 1.1.1.27 & M & $\mathrm{TC}$ & $\mathrm{T}$ \\
\hline $\begin{array}{l}\text { Malate dehydrogenase } \\
-\mathrm{NAD}^{+}(\mathrm{MDH})\end{array}$ & 1.1.1.37 & $\mathrm{L}$ & $\mathrm{TC}$ & $\mathrm{D}$ \\
\hline $\begin{array}{l}\text { Malate dehydrogenase } \\
\text {-NADP } \\
+(M E)\end{array}$ & 1.1 .1 .40 & $\mathrm{~L}$ & $\mathrm{TC}$ & $\mathrm{T}$ \\
\hline $\begin{array}{l}\text { Phosphoglucomutase } \\
\text { (PGM) }\end{array}$ & 5.4 .2 .2 & M & $\mathrm{TC}$ & Mo \\
\hline $\begin{array}{l}\text { Superoxide dismutase } \\
\text { (SOD) }\end{array}$ & 1.15.1.1 & $\mathrm{L}$ & TBE/TEM & $\mathrm{D}$ \\
\hline
\end{tabular}

EC n. = Enzyme Commission number; $\mathrm{G}=$ gill; $\mathrm{H}=$ heart; $\mathrm{L}=$ liver; $\mathrm{M}=$ muscle; TEM = Tris/EDTA/Maleate $\mathrm{pH} 7.4$ (Shaw and Prasad, 1970); $\mathrm{TBE}=$ Tris/EDTA/borate $\mathrm{pH} 8.6$ (Boyer et al., 1963$) ; \mathrm{III} \mathrm{TC}=$ Tris/citrate $\mathrm{pH} 7.0$ (Shaw and Prasad, 1970); $\mathrm{D}=$ dimeric; $\mathrm{Mo}=$ monomeric; $\mathrm{T}=$ tetrameric. 
Table 2 - Allele frequency and the homogeneity chi square test $\left(\chi^{2}\right)$ for each of the 20 loci detected by the corn gel electrophoresis technique in Hypostomus nigromaculatus and Hypostomus cf. nigromaculatus from the Atlântico Stream (Paraná State, Brazil) ( $\mathrm{p}=$ chi square probability).

\begin{tabular}{|c|c|c|c|c|c|}
\hline Locus & Allele & $\begin{array}{c}\text { Hypostomus } \\
\text { nigromaculatus }\end{array}$ & $\begin{array}{c}H . \text { cf. } \\
\text { nigromaculatus }\end{array}$ & $\chi^{2}$ & $\mathrm{p}$ \\
\hline Aat-1 & $a$ & 1.00 & 1.00 & 0.00 & 1.00 \\
\hline \multirow[t]{2}{*}{ Aat-2 } & $a$ & 1.00 & - & 60.00 & 0.00 \\
\hline & $b$ & - & 1.00 & & \\
\hline Adh-1 & $a$ & 1.00 & 1.00 & 0.00 & 1.00 \\
\hline Est-1 & $a$ & 1.00 & 1.00 & 0.00 & 1.00 \\
\hline Est-2 & $a$ & 1.00 & 1.00 & 0.00 & 1.00 \\
\hline Est-3 & $a$ & 1.00 & 1.00 & 0.00 & 1.00 \\
\hline Est-4 & $a$ & 1.00 & 1.00 & 0.00 & 1.00 \\
\hline \multirow[t]{2}{*}{$G d h-1$} & $a$ & - & 1.00 & 36.00 & 0.00 \\
\hline & $b$ & 1.00 & - & & \\
\hline$G 3 p d h-1$ & $a$ & 1.00 & 1.00 & 0.00 & 1.00 \\
\hline$G 3 p d h-2$ & $a$ & 1.00 & 1.00 & 0.00 & 1.00 \\
\hline \multirow[t]{3}{*}{$G p i-A$} & $a$ & 0.87 & - & 60.00 & 0.00 \\
\hline & $b$ & - & 1.00 & & \\
\hline & $c$ & 0.13 & - & & \\
\hline \multirow[t]{3}{*}{$G p i-B$} & $a$ & 0.80 & 0.17 & 39.60 & 0.00 \\
\hline & $b$ & 0.03 & 0.83 & & \\
\hline & $c$ & 0.17 & & & \\
\hline \multirow[t]{2}{*}{ Idh-1 } & $a$ & - & 1.00 & 60.00 & 0.00 \\
\hline & $b$ & 1.00 & - & & \\
\hline \multirow[t]{2}{*}{$L d h-A$} & $a$ & 1.00 & - & 60.00 & 0.00 \\
\hline & $b$ & - & 1.00 & & \\
\hline \multirow[t]{2}{*}{$L d h-B$} & $a$ & 1.00 & 0.73 & 9.23 & 0.00 \\
\hline & $b$ & - & 0.27 & & \\
\hline \multirow[t]{2}{*}{$M d h-A$} & $a$ & 1.00 & - & 60.00 & 0.00 \\
\hline & $b$ & - & 1.00 & & \\
\hline$M d h-B$ & $a$ & 1.00 & 1.00 & 0.00 & 1.00 \\
\hline$M e-1$ & $a$ & 1.00 & 1.00 & 0.00 & 1.00 \\
\hline Pgm-1 & $a$ & 1.00 & 1.00 & 0.00 & 1.00 \\
\hline Sod-1 & $a$ & 1.00 & 1.00 & 0.00 & 1.00 \\
\hline
\end{tabular}

$H o=0.0167 \pm 0.0745$, while for $H$. nigromaculatus the values were $H e=0.0291 \pm 0.0911$ and $H o=0.0200 \pm 0.0652$.

Wright's (Wright, 1978) F statistics $F_{\text {IS }}$ for estimating the excess of homozygotes was calculated for each locus. Mean values were $F_{\mathrm{IS}}=0.312$ for $H$. nigromaculaus and 0.455 for $H$. cf. nigromaculatus. The unbiased genetic identity (I) and genetic distance (D) of Nei (1978) were estimated as $\mathrm{I}=0.6515$ and $\mathrm{D}=0.4285$.

\section{Discussion}

H. nigromaculatus had already been described by Schubart (1964), through specimens collected in the Mogí-Guaçu River, São Paulo State. Species of Hypostomus

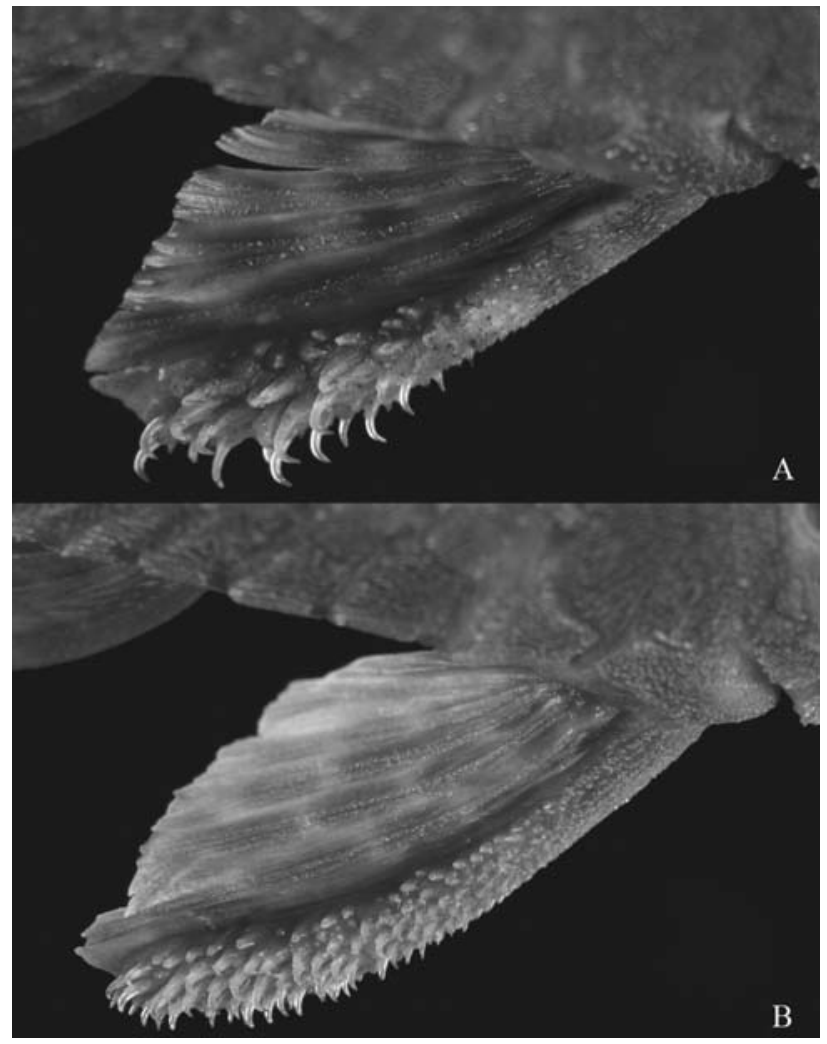

Figure 3 - Pectoral fins. A. Hypostomus nigromaculatus. B. Hypostomus cf. nigromaculatus.

are widely distributed in medium or small streams of the upper Paraná River basin and morphological variations are commonly found among specimens of distant streams. Works on the genetics of these species are scarce in the literature. Rubert et al. (2008) found cytogenetic differences among populations of $H$. nigromaculatus from the MogíGuaçu River and streams of the Tibagi River basin. $H$. nigromaculatus and $H$. cf. nigromaculatus are both smallsized and have a dorso-ventrally depressed body, with relatively short pectoral and dorsal fins, and a large number of teeth and plates in the lateral areas of the abdomen. These similarities make correct identification difficult and indicate that they are probably phylogenetically similar species. However, H. nigromaculatus always presents evident dark spots on the body and fins, while $H$. cf. nigromaculatus usually presents light spots (not always evident) and sometimes some dark spots. In addition, $H$. nigromaculatus has a shorter standard length and smaller eyes than $H$. cf. nigromaculatus. There are also differences in relation to the pectoral fins, which are shorter and claviform in $H$. nigromaculatus, and the odontodes, which are more concentrated in the distal portion of the spine than in $H$. cf. nigromaculatus (Figure 4).

Studies of enzymatic loci have been used to verify the existence of species with doubtful taxonomic status or sibling species among sympatric morphotypes (Thorpe and Solé-Cava, 1994). Zawadzki et al. (2004), on studying $H$. 
hermanni and three morphotypes of Hypostomus collected in the Keller Stream, detected three diagnostic loci for
Hypostomus sp. 1 (Gdh-A, G6pdh-A and G6pdh-B), eight for Hypostomus sp. 2 (sAta-B, G3pdh-A, G3pdh-B, Gpi-B,

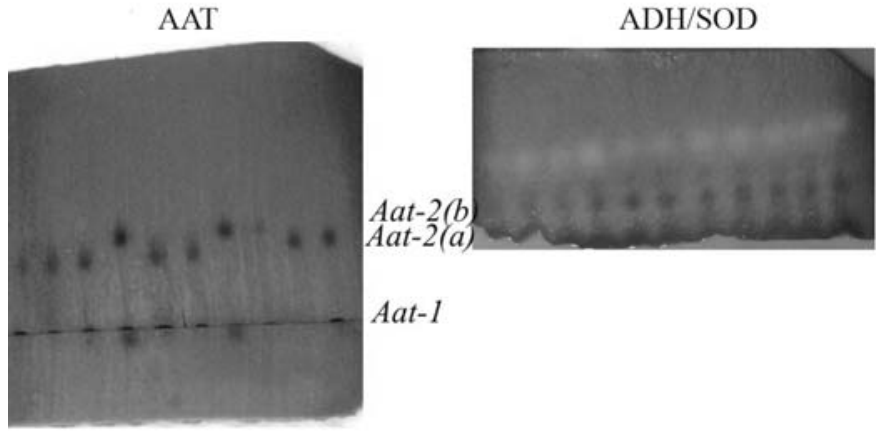

$\mathrm{n} \mathrm{n} \mathrm{n}$ c $\mathrm{n} \mathrm{n}$ c $\mathrm{c} \mathrm{n} \mathrm{n}$
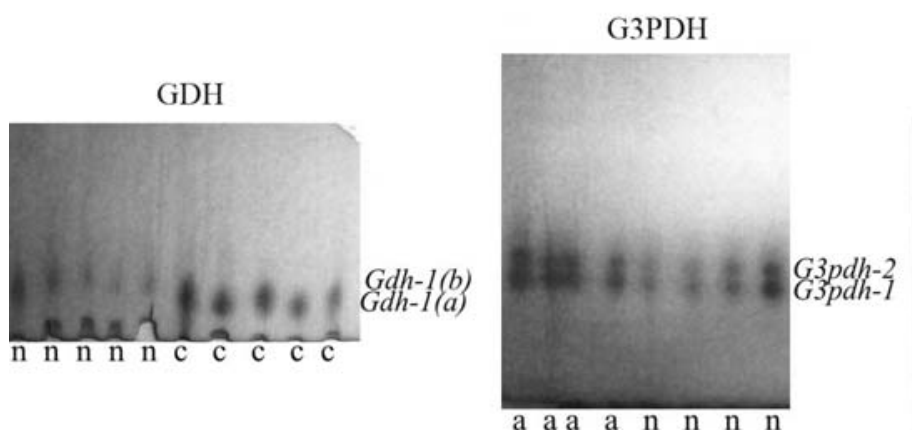

$\mathrm{MDH}$

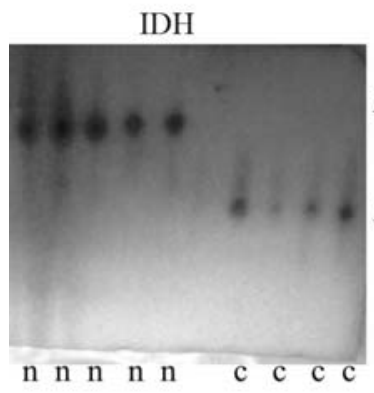

Idh-I(b)
Idh-I(a)

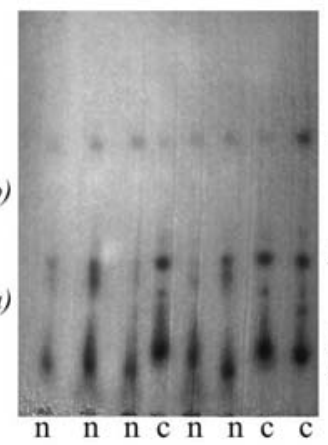

PGM

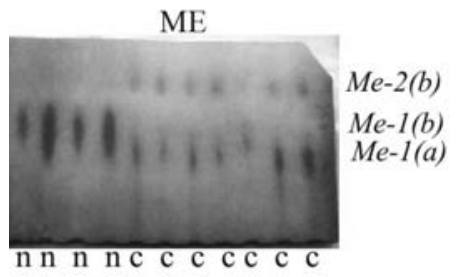

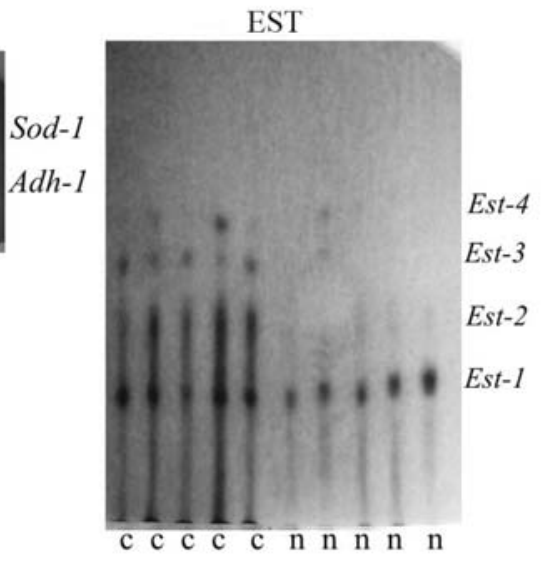

GPI

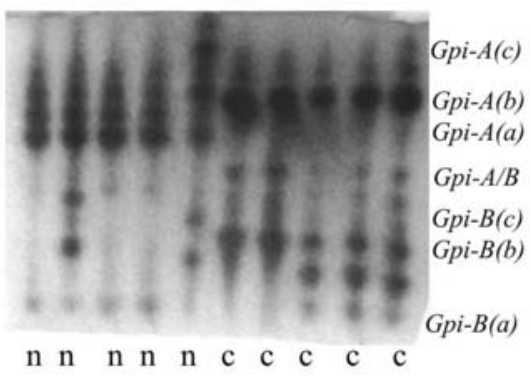

LDH

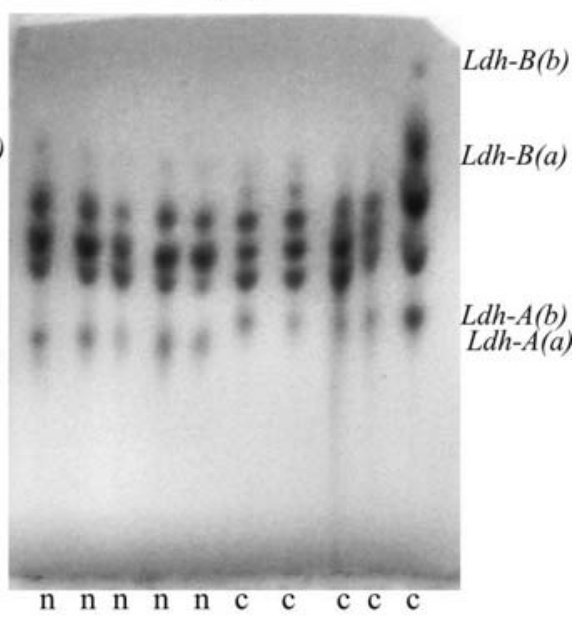

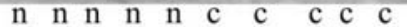

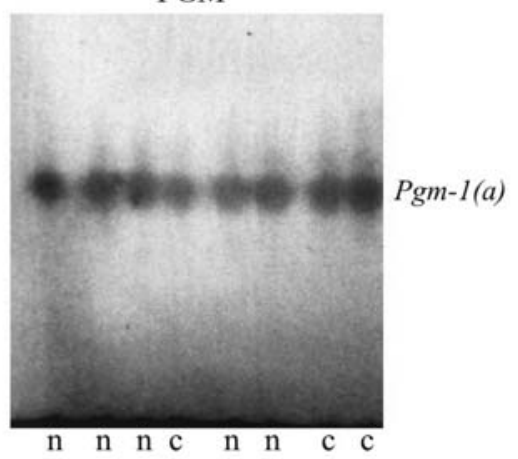

Figure 4 - Electrophoretic patterns of 12 enzyme system analyses in corn starch gel for two morphotypes from the Atlântico Stream, Paraná State, Brazil. $\mathrm{n}=$ Hypostomus nigromaculatus $; \mathrm{c}=$ Hypostomus $\mathrm{cf}$. nigromaculatus . 
Ldh-A, Ldh-B, sMdh-B and sMdhp-A) and one for Hypostomus sp. 3 (sMdh-A), and so concluded that Hypostomus sp. 1, Hypostomus sp. 2 and Hypostomus sp. 3 were three different species.

In the present work, Glucose-6-phosphate isomerase (GPI) was the enzyme system which presented the largest observed heterozysosity (0.3425). With good expression in three tissues (gill, liver and muscle), this system presented two loci: $G p i-A$ with two alleles and $G p i-B$ with three. This enzyme can be used as a quick way of differentiating the two morphotypes, since $G p i-A$ is a diagnostic locus. Studies analyzing other fish of the family Loricariidae have also observed the existence of two loci for this same enzyme (Zawadzki et al., 2000; Fisch-Muller et al., 2001).

The occurrence of few polymorphic loci $(10 \%)$ was verified for the two morphotypes. Inbreeding is a probable explanation for the low genetic variability in these taxa, as suggested by Zawadzki et al. (1999) for Hypostomus derbyi and H. myersi of the Iguaçu River (Paraná State, Brazil). Armored catfishes of the genus Hypostomus have sedentary habits, which lead to mating inside a family group, thus resulting in low genetic variability. On the other hand, inbreeding probably would not lead to fixation of alternative alleles in six loci. The fixed differences observed at the six loci are probably the result of drift fixation of different alleles over evolutionary time, before these different species became syntopic.

Factors that can cause the population not to be in Hardy-Weinberg equilibrium for a certain locus can be inbreeding, assortative mating and natural selection. In this case, we think the best hypothesis is inbreeding, since they are sedentary organisms, although we cannot caste aside possible gel-interpretation errors.

Nei's unbiased genetic identity (I) and genetic distance (D) indicate that one is dealing with two genetically different morphotypes. Taking into account the parameters proposed by Thorpe and Solé-Cava (1994), who analyzed the values of genetic identity obtained for different phylogenetic levels, populations that belong to the same species have I values superior to 0.85 . On the other hand, for species belonging to the same genus, I values are between 0.35 and 0.85 . Finally, for species belonging to a different genus, I values are inferior to 0.35 . Nei's genetic identity between $H$. nigromaculatus and $H$. cf. nigromaculatus was $\mathrm{I}=0.6515$, thereby indicating they are different species of Hypostomus. Nei's genetic distance (Nei, 1978) corresponds to mean nucleotide substitutions per locus accumulated in the populations since they diverged from a common ancestor; i.e. substitution is proportional to evolutionary time (Dobzhansky et al., 1977; Thorpe, 1982; Thorpe and Solé-Cava, 1994).

Even though they possess few morphological differences, there are significant genetic differences between the two morphotypes, thus showing reproductive isolation one from the other, and indicating that they belong to different Hypostomus species.

Paiva et al. (2005) demonstrated the existence of two undescribed species of Hypostomus in the Maringá Stream. They were caught just $10 \mathrm{~km}$ from the place where $H$. nigromaculatus and $H$. cf. nigromaculatus were collected, in the same river basin (Pirapó). Zawadzki et al. (2004) were also able to reveal the presence of three other undescribed species of Hypostomus in the Keller Stream, a tributary of the Ivaí River, $37 \mathrm{~km}$ from the Maringá Stream. Since six new Hypostomus species have been revealed to date in a small area of northwestern Paraná State, there should be many other undescribed species in the streams and rivers of the state. The ichthyofauna of Paraná State is poorly known. Therefore, we propose more widespread studies in the biochemical and molecular systematics of fish to improve our understanding.

\section{Acknowledgments}

The authors wish to thank Alessandro G. Bifi, Hector S. Vera and Pardhal for helping in the field work, Corn Products, Brazil, for providing penetrose 50, and Jaime L. Pereira for helping with map elaboration. Kennya Fernanda Ito received grants from CAPES (Coordenação de Aperfeiçoamento do Pessoal de Nível Superior).

\section{References}

Alfenas AC (2006) Eletroforese e Marcadores Bioquímicos em Plantas e Microrganismos. 2nd edition. UFV, Viçosa, 627 pp.

Birindelli JLO, Zanata AM and Lima FCT (2007) Hypostomus chrysostyktos, a new species of armored catfish (Siluriformes, Loricariidae) from rio Paraguaçu, Bahia State, Brazil. Neotrop Ichthyol 5:271-278.

Boyer SH, Fainer DC and Naughton MA (1963) Myoglobin: Inherited structural variation in man. Science 140:1228-1231.

Cardoso AR and Silva JFP (2004) Two new species of the genus Hemiancistrus Bleeker (Teleostei, Siluriformes, Loricariidae) from the upper Uruguay River basin. Neotrop Ichthyol 2:1-8.

Dobzhansky T, Ayala FJ, Stebbins GL and Valentine JW (1977) Evolution. W.H. Freeman and Company, San Francisco, 572 pp.

Fisch-Muller S, Mazzoni R and Weber C (2001) Genetic and morphological evidences for two new sibling species of Ancistrus (Siluriformes, Loricariidae) in the upper rio Tocantins drainage, Brazil. Ichthyol Explor Freshwaters 12:289-304.

Jerep FC, Shibatta OA and Zawadzki CH (2007) A new species of Hypostomus Lacépède, 1803 (Siluriformes, Loricariidae) from the upper rio Paraná basin, Southern Brazil. Neotrop Ichthyol 5:435-442.

Murphy RW, Sites JW, Buth DG and Haufler CH (1996) Proteins: Isozyme electrophoresis. In: Hillis DM, Moritz C and Mable BK (eds) Molecular Systematics. 2nd edition. Sinauer Associates, Massachusetts, pp 51-120. 
Nei M (1978) Estimation of average heterozygosity and genetic distance from a small number of individuals. Genetics 89:583-590.

Nelson JS (1994) Fishes of the World. 3rd edition. John Wiley and Sons, New York, 600 pp.

Paiva S, Renesto E and Zawadzki CH (2005) Genetic variability of Hypostomus (Teleostei, Loricariidae) from the Ribeirão Maringá, a stream of the upper Rio Paraná basin, Brazil. Genet Mol Biol 28:370-375.

Pasteur N, Pasteur G, Bonhomme F, Catalan J and BrittonDavidian J (1988) Practical Isozyme Genetics. Ellis Horwood Limited, Chichester, 215 pp.

Pereira EHL and Oyakawa OT (2003) Isbrueckerichthys epakmos, a new species of loricariid catfish from the rio Ribeira do Iguape basin, Brazil (Teleostei, Siluriformes). Neotrop Ichthyol 1:3-9.

Reis RE, Kullander SO and Ferraris CJ (2003) Check List of the Freshwater Fishes of South America. Edipucrs, Porto Alegre, $729 \mathrm{pp}$.

Reis RE, Pereira EHL and Armbruster JW (2006) Delturinae, a new loricariid catfish subfamily (Teleostei, Siluriformes), with a revision of Delturus and Hemipsilichthys. Zool J Linn Soc 147:277-299.

Renesto E, Zawadzki CH and Revaldaves E (2000) Genetic evidence for two species of the genus Pimelodus Lacépède, 1803 (Siluriformes, Pimelodidae) in the Iguaçu River (Brazil). Genet Mol Biol 23:809-813.

Renesto E, Zawadzki CH and Revaldaves E (2001) Biochemical taxonomy of Crenicichla (Pisces, Perciformes, Cichlidae) of the Iguaçu River, Brazil. Braz Arch Biol Technol 44:15-22.

Renesto E, Zawadzki DH and Paiva S (2007) differentiation and relationships within Hypostomus Lacépède, 1803 (Teleostei, Loricariidae) from the upper Paraguay River basin, Brazil. Biochem Syst Ecol 35:869-876.

Rubert M, Zawadzki, CH and Giuliano-Caetano L (2008) Cytogenetic differentiation among populations of Hypostomus nigromaculatus (Schubart, 1964) (Siluriformes, Loricariidae). Neotrop Ichthyol 6:93-100.

Schaefer SA (1998) Conflict and resolution: Impact of new taxa on phylogenetic studies of the Neotropical cascudinhos (Siluriformes, Loricariidae). In: Malabarba LR, Reis RE, Vari RP, Lucena ZMS and Lucena CAS (eds) Phylogeny and Classification of Neotropical Fishes. Edipucrs, Porto Alegre, pp 375-400.
Schubart O (1964) Sobre algumas Loricariidae da bacia do Rio Mogi Guaçu. Bol Mus Nac Rio de Janeiro 251:1-19.

Shaw CR and Prasad R (1970) Starch gel electrophoresis of enzymes: A compilation of recipes. Biochem Genet 4:297320.

Thorpe JP (1982) The molecular clock hypothesis: Biochemical evolution, genetic differentiation and systematics. Annu Rev Ecol Syst 13:139-168.

Thorpe JP and Solé-Cava AM (1994) The use of allozyme electrophoresis in invertebrate systematics. Zool Scr 23:3-18.

Val AL, Schwantes AR, Schwantes MLB and Luca PH (1981) Amido hidrolisado de milho como suporte eletroforético. Cienc Cult 33:737-741 (Abstract in English).

Yeh FC and Boyle TJB (1997) Population genetic analysis of co-dominant and dominant markers and quantitative traits. Belg J Bot 129:156-157.

Weber C (2003) Family Loricariidae: Subfamily Hypostominae. In: Reis RE, Kullander SO and Ferraris JR CJ (eds) Check List of the Freshwater Fish of South America. Edipucrs, Porto Alegre, pp 351-372.

Wright S (1978) Evolution and the genetics of populations. Variability within and among natural populations. University of Chicago Press, Chicago, 590 pp.

Zawadzki CH, Renesto E and Bini LM (1999) Genetic and morphometric analysis of three species of the genus Hypostomus Lacépède, 1803 (Osteichthyes, Loricariidae) from the Rio Iguaçu basin (Brazil). Rev Suisse Zool 106:91-105.

Zawadzki CH, Reis E and Renesto E (2000) Allozyme discrimination of three species of Loricariichthys (Siluriformes, Loricariidae) from Southern Brazil. Rev Suisse Zool 107:663-674.

Zawadzki CH, Machado MFPS and Renesto E (2001) Differential expression for tissue-specific isozymes in the three species of Hypostomus Lacépède, 1803 (Teleostei, Loricariidae). Biochem Syst Ecol 29:911-922.

Zawadzki CH, Alves AL, Renesto E and Oliveira C (2004) Biochemical evidence of a possible new species of Neoplecostomus (Teleostei, Loricariidae) from the upper Rio Paraná basin, Brazil. Biochem Syst Ecol 32:573-58.

Associate Editor: Fausto Foresti

License information: This is an open-access article distributed under the terms of the Creative Commons Attribution License, which permits unrestricted use, distribution, and reproduction in any medium, provided the original work is properly cited. 